\section{Examen de spécialiste FMH en dermatologie et vénéréologie 2004}

Le 25 novembre 2004 à Lausanne, s'est déroulé l'examen de spécialiste en dermatologie et vénéréologie. Cet examen est obligatoire pour obtenir le titre fédéral de spécialiste en dermatologie et vénéréologie.

15 candidats se sont présentés et ont réussi. Le Comité de la SSDV est heureux de pouvoir féliciter les médecins suivants.

Dr Andreas Arnold, Bâle

Dr Helmut Beltraminelli, Bâle

Dr Angela Brögli, Zurich

Dr Claudio Mario Cipolat, Zurich

Dr Thomas Gaudin, Genève

Dr Jivko Kamarachev, Zurich

Dr Stéphane Kuenzli, Genève

Dr Michèle Kuster-Iten, Zurich

Dr Poch Lor, Zurich

Dr Martin Schermesser, Zurich

Dr Lisa Sharon Steinmann, Zurich

Dr Mouna Skaria, Genève

Dr Lisette Stucki, Genève

Dr John Marco Venuti, Zurich

Dr Karoline Zepter, Zurich

La Commission des examens de la SSDV est présidée par le Prof. Dr. Stanislaw Büchner de Bâle, en 2004 elle était composée des Prof. Daniel Hohl, Thomas Hunziker et Ralph Trüeb, du PD Dr Luca Borradori, des Drs Michel Camenzind, René Meyrat, Francesco Pelloni, Henri Perroud et Thomas Rakosi.

\section{Dr Félix Gueissaz}

Président

\section{5th International Symposium on Contact Dermatitis (ISCD) in Conjunction with 5th International Symposium on Irritant Contact Dermatitis (ISICD)}

\author{
Elysium Beach Resort, Paphos, Cyprus \\ November 6-9, 2005
}

\section{Second Announcement and Late Call for Papers}

The 15th International Symposium on Contact Dermatitis (ISCD) in conjunction with the 5th International Symposium on Irritant Contact Dermatitis (ISICD) will be held in Paphos, Cyprus, on November 6-9, 2005.

Plenary sessions, symposia and poster sessions will cover the different aspects of contact dermatitis. Clinicians and researchers in the field of contact dermatitis are invited to exchange ideas and discuss issues in this area in the stimulating environment of the symposium.

The symposium topics: epidemiology, clinical aspects, prevention, non-invasive methods, biochemical and immunological aspects, in vitro techniques and regulatory aspects. You are invited to submit your proposal online by April 30 via the symposium website.

For further information, please contact the symposium secretariat:

Ortra Ltd., 1 Nirim Street, PO Box 9352,

Tel Aviv 61092 (Israel), Tel. +972 36384444 ,

Fax+97236384455, E-Mail conderm@ortra.com, website www.ortra.com/conderm. 